Review

\title{
Boeing's Autonomous Military Aircraft
}

\author{
Relly Victoria Virgil Petrescu \\ ARoTMM-IFToMM, Bucharest Polytechnic University, Bucharest, (CE) Romania
}

Article history

Received: 02-03-2019

Revised: 04-03-2019

Accepted: 15-06-2019

Email: rvvpetrescu@gmail.com

Abstract: Boeing will build a self-propelled military aircraft to accompany US combat aircraft during missions. Boeing's autonomous airplane will achieve superior flying performance to those pilots even with the most modern aircraft. If technology advances and becomes more accessible to civilians, why would not this happen in the military domain? US, Russian, Australian and British armies have already been using advanced technology for decades were civilians just dream, these technologies being totally secret and forbidden to the general public and mass media. Boeing, which manufactures commercial and military aircraft, wants to revolutionize the "art of war" and introduce a state-of-the-art, self-propelled aircraft into the battlefield to adapt to a variety of complex military missions. They called it the Boeing Airpower Teaming System because it will team up well with military pilots during reconnaissance missions or even hostility or defensive missions. This autonomous airplane will play the role of additional help designed to significantly reduce the risks to which soldiers are often exposed. The stand-alone aircraft can be sent both on reconnaissance missions and for attack operations (either for defense or for the removal of targets considered terrorist). He will be able to intercept the enemy in good time and to annihilate it. It will be manufactured in Australia and it will have a length of more than 11 meters and Boeing promises autonomy of over 3,700 kilometers (2,000 nautical miles). Obviously, the company will not only produce for Americans or Australians. Any government will be able to purchase the autonomous airplane if it allows it (at least theoretically, because sales of such products are basically also with special political agreements). It is very likely that in the future, we will not even have much need for soldiers if the missions are carried out by autonomous airplanes or robots. Good news, as democracies have come to pay citizens to motivate them to become soldiers.

Keywords: Boeing, Boeing's Autonomous Airplane, Boeing Airpower Teaming System, British Airways, Americans or Australians Airways, 3,700 Kilometers Autonomy

\section{Introduction}

Boeing is a US civil and military aircraft manufacturer based in Chicago, USA. Boeing is Pentagon's second largest provider of aerospace and technological equipment after Lockheed Martin. The company is present in 70 countries around the world.

The company is organized into two main divisions:

- Boeing Commercial Airplanes

- Boeing Integrated Defense Systems

In June 2008, there were 12,000 commercial airplanes made by Boeing, accounting for about $75 \%$ of the entire commercial fleet in the world.
Civil Aircraft:

- $\quad$ Boeing 247

- Boeing 367-80

- Boeing 707

- $\quad$ Boeing 717

- $\quad$ Boeing 727

- $\quad$ Boeing 737

- $\quad$ Boeing 747

- $\quad$ Boeing 757

- Boeing 767

- $\quad$ Boeing 777

- $\quad$ Boeing 787

Combat planes: 
- McDonnell Douglas F/A-18 Hornet

- Boeing F/A-18E/F Super Hornet

- Boeing EA-18G Growler

- F-15 Eagle

- F-15 Strike Eagle

Bombers:

- B-1 Lancer

- B-2 Spirit

- B-17 Flying Fortress

- B-29 Superfortress

- B-47 Stratojet

- B-52 Stratofortress

Tank airplanes:

- KC-135 Stratotanker

- KC-97 Stratotanker

- Strategic transport planes

- C-17 Globemaster III

Special Aircraft:

- Boeing E-3 SENTRY AWACS

- Boeing E-4B NAOC

- Boeing E-6 MERCURY

- Boeing E-8C JSTARS

Attack helicopters:

- Boeing AH-64 Apache

- Boeing RAH-66 Comanche

Transport helicopters:

- $\mathrm{CH}-47$ Chinook

- H-21 Shawnee

- $\mathrm{CH}-46$ Sea Knight

Experimental Aircraft:

- $\quad$ Boeing X-36

- Boeing X-32 JSF

- Boeing X-45

- Boeing XB-15

- Boeing X-43

- Boeing X-48

Supersonic passenger airplanes:

- $\quad$ Boeing 2707

In March 1910, William E. Boeing bought Heath Shipyard in Seattle on the Duwamish River, which later became his first aircraft factory. Boeing was incorporated into Seattle by William Boeing on July 15, 1916, as "Pacific Aero Products Co.". Boeing was later embedded in Delaware; the original certificate of the establishment was deposited with Delaware State Secretary on July 19, 1934. Boeing, who studied at Yale University, originally worked in the wood industry, where he became rich and learned about wooden structures. This knowledge proved to be invaluable in the design and subsequent assembly of planes. The company stayed in Seattle to take advantage of the local offer of spruce wood.

One of the two B\&W floods built by George Conrad Westervelt, an American engineer, flew on June 15, 1916. Boeing and Westervelt decided to build the B\&W hydrogen after they flew with Curtiss. Boeing bought a Glenn Martin "Flying Birdcage" (named by everyone who held it together) and was taught to fly by Glenn Martin himself. Boeing crashed into Birdcage soon and when Martin informed Boeing that spare parts would not be available for months, Boeing realized he could build the plane at that time. $\mathrm{He}$ and Cdr's friend. G.C. Westervelt agreed to build a better aircraft and soon produced the $\mathrm{B} \& \mathrm{~W}$ seaplane. The first Boeing was gathered in a hangar near the lake, located on the northeast shore of Lake Seattle. Many of Boeing's early planes were seaplanes.

On April 6, 1917, the US declared war on Germany and entered the First World War. On May 9, 1917, the company became the company "Boeing Airplane Company". During the war, Boeing knew that the American ship needed training aids. So, Boeing sent two new Cs models to Pensacola, Florida, where the planes were fired for the Navy. Marina liked Model $\mathrm{C}$ and ordered another 50 people. The company moved its operations to an old building, known as Boeing Plant 1, located on the Lower Duwamish River, Washington.

At the end of the First World War of 1918, a large surplus of cheap and used military aircraft flooded the commercial airplane market, preventing airlines from selling any new aircraft, which led many of them. Others, including Boeing, began selling other products. Boeing built locker rooms, counters and furniture along with flat-bottomed boats called Sea Sleds.

In 1919, Boeing B-1 made the first flight (Hosted a pilot and two passengers and several emails). Within eight years, he made international flights by plane from Seattle to Victoria, British Columbia. On May 24, 1920, Boeing 8 made his first flight. It was the first plane flying over Mount Rainier.

In 1923, Boeing competed against Curtiss to develop a fighter for the US Army Air Service. Although Curtiss completed his project and received the contract, Boeing continued to develop his PW-9 fighter. The plane, along with the Boeing P-12/F4B fighter, made Boeing an important aircraft manufacturer over the next decade. 
In 1925 , Boeing built his 40 e-mail model for the US government. to use on flight routes. In 1927, an improved version of this $40 \mathrm{~A}$ aircraft was built that won the US mail order to deliver mail between San Francisco and Chicago. The $40 \mathrm{~A}$ also had a passenger cabin that housed two.

In the same year, Boeing created an airline called Boeing Air Transport, which merged a year later with Pacific Air Transport and Boeing Airline. The first flight to the airline was on July 1, 1927. In 1929, the company merged with Pratt and Whitney, the production company Hamilton Aero Manufacturing and Chance Vought, under the new United Aircraft and Transport Corporation. The merger was followed by the acquisition of Sikorsky Manufacturing Corporation, Stearman Aircraft Corporation and Standard Metal Propeller Company. United Aircraft then acquired the national air transport in 1930.

On July 27, 1928, the 12-passenger Boeing 80 biplane made its first flight. With three engines, Boeing's first aircraft was built with the sole intention of being a passenger transport. A modernized version, 80A, carrying eighteen passengers, made the first flight in September 1929 (Rulkov et al., 2016; Agarwala, 2016; Babayemi, 2016; Gusti and Semin, 2016; Mohamed et al., 2016; Wessels and Raad, 2016; Rajput et al., 2016; Rea and Ottaviano, 2016; Zurfi and Zhang, 2016a; 2016b; Zheng and Li, 2016; Buonomano et al., 2016a; 2016b; Faizal et al., 2016; Ascione et al., 2016; Elmeddahi et al., 2016; Calise et al., 2016; Morse et al., 2016; Abouobaida, 2016; Rohit and Dixit, 2016; Kazakov et al., 2016; Alwetaishi, 2016; Riccio et al., 2016a; 2016b; Iqbal, 2016; Hasan and El-Naas, 2016; Al-Hasan and Al-Ghamdi, 2016; Jiang et al., 2016; Sepúlveda, 2016; Martins et al., 2016; Pisello et al., 2016; Jarahi, 2016; Mondal et al., 2016; Mansour, 2016; Al Qadi et al., 2016b; Campo et al., 2016; Samantaray et al., 2016; Malomar et al., 2016; Rich and Badar, 2016; Hirun, 2016; Bucinell, 2016; Nabilou, 2016b; Barone et al., 2016; Chisari and Bedon, 2016; Bedon and Louter, 2016; dos Santos and Bedon, 2016; Minghini et al., 2016; Bedon, 2016; Jafari et al., 2016; Chiozzi et al., 2016; Orlando and Benvenuti, 2016; Wang and Yagi, 2016; Obaiys et al., 2016; Ahmed et al., 2016; Jauhari et al., 2016; Syahrullah and Sinaga, 2016; Shanmugam, 2016; Jaber and Bicker, 2016; Wang et al., 2016; Moubarek and Gharsallah, 2016; Amani, 2016; Shruti, 2016; Pérezde León et al., 2016; Mohseni and Tsavdaridis, 2016; Abu-Lebdeh et al., 2016; Serebrennikov et al., 2016; Budak et al., 2016; Augustine et al., 2016; Jarahi and Seifilaleh, 2016; Nabilou, 2016a; You et al., 2016; AL Qadi et al., 2016a; Rama et al., 2016; Sallami et al., 2016; Huang et al., 2016; Ali et al., 2016; Kamble and Kumar, 2016; Saikia and Karak, 2016; Zeferino et al., 2016; Pravettoni et al., 2016; Bedon and Amadio, 2016; Chen and $\mathrm{Xu}, 2016$; Mavukkandy et al., 2016; Yeargin et al., 2016; Madani and Dababneh, 2016;
Alhasanat et al., 2016; Elliott et al., 2016; Suarez et al., 2016; Kuli et al., 2016; Waters et al., 2016; Montgomery et al., 2016; Lamarre et al., 2016; Petrescu, 2012b; Aversa et al., 2017a; 2007b; 2016a; 2016b; 2016c; 2016d; 2016e; 2016f; 2016g; 2016h; 2016i; 2016j; 2016k; 20161; 2016m; 2016n; 2016o; Petrescu and Petrescu, 2016; 2015a; 2015b; 2015c; 2015d; 2015e; 2014a; 2014b; 2014c; 2014d; 2014e; 2014f; 2014g; 2014h; 2014i; 2013a; 2013b; 2013c; 2013d; 2013e; 2013f; 2013g; 2012; 2011; 2005a; 2005b; 2005c; 2005d; 2003; 2002a; 2002b; 2000a; 2000b; 1997a; 1997b; 1997c; 1995a; 1995b; Petrescu, 2018; 2015a; 2015b; 2012; Petrescu et al., 2016; 2017a; $2017 \mathrm{~b} ; 2017 \mathrm{c} ; 2017 \mathrm{~d} ; 2018 \mathrm{a} ; 2018 \mathrm{~b} ; 2018 \mathrm{c} ; 2018 \mathrm{~d}$; Petrescu and Calautit, 2016a; 2016b; Daud et al., 2008; Taher et al., 2008; Zulkifli et al., 2008; Pourmahmoud, 2008; Pannirselvam et al., 2008; Ng et al., 2008; ElTous, 2008; Akhesmeh et al., 2008; Nachiengtai et al., 2008; Moezi et al., 2008; Boucetta, 2008; Darabi et al., 2008; Semin and Bakar, 2008; Al-Abbas, 2009; Abdullah et al., 2009; Abu-Ein, 2009; Opafunso et al., 2009; Semin et al., 2009a; 2009b; 2009c; Zulkifli et al., 2009; Ab-Rahman et al., 2009; Abdullah and Halim, 2009; Zotos and Costopoulos, 2009; Feraga et al., 2009; Bakar et al., 2009; Cardu et al., 2009; Bolonkin, 2009a; 2009b; Nandhakumar et al., 2009; Odeh et al., 2009; Lubis et al., 2009; Fathallah and Bakar, 2009; Marghany and Hashim, 2009; Kwon et al., 2010; Aly and Abuelnasr, 2010; Farahani et al., 2010; Ahmed et al., 2010; Kunanoppadon, 2010; Helmy and El-Taweel, 2010; Qutbodin, 2010; Pattanasethanon, 2010; Fen et al., 2011; Thongwan et al., 2011; Theansuwan and Triratanasirichai, 2011; Al Smadi, 2011; Tourab et al., 2011; Raptis et al., 2011; Momani et al., 2011; Ismail et al., 2011; Anizan et al., 2011; Tsolakis and Raptis, 2011; Abdullah et al., 2011; Kechiche et al., 2011; Ho et al., 2011; Rajbhandari et al., 2011; Aleksic and Lovric, 2011; Kaewnai and Wongwises, 2011; Idarwazeh, 2011; Ebrahim et al., 2012; Abdelkrim et al., 2012; Mohan et al., 2012; Abam et al., 2012; Hassan et al., 2012; Jalil and Sampe, 2013; Jaoude and El-Tawil, 2013; Ali and Shumaker, 2013; Zhao, 2013; El-Labban et al., 2013; Djalel et al., 2013; Nahas and Kozaitis, 2014).

\section{Materials and Methods}

Boeing will build a self-propelled military aircraft to accompany US combat aircraft during missions. Boeing's autonomous airplane will achieve superior flying performance to those pilots even with the most modern aircraft.

If technology advances and becomes more accessible to civilians, why would not this happen in the military domain? US, Russian, Australian and British armies have already been using advanced technology for decades were civilians just dream, these technologies being totally secret and forbidden to the general public and mass media. 


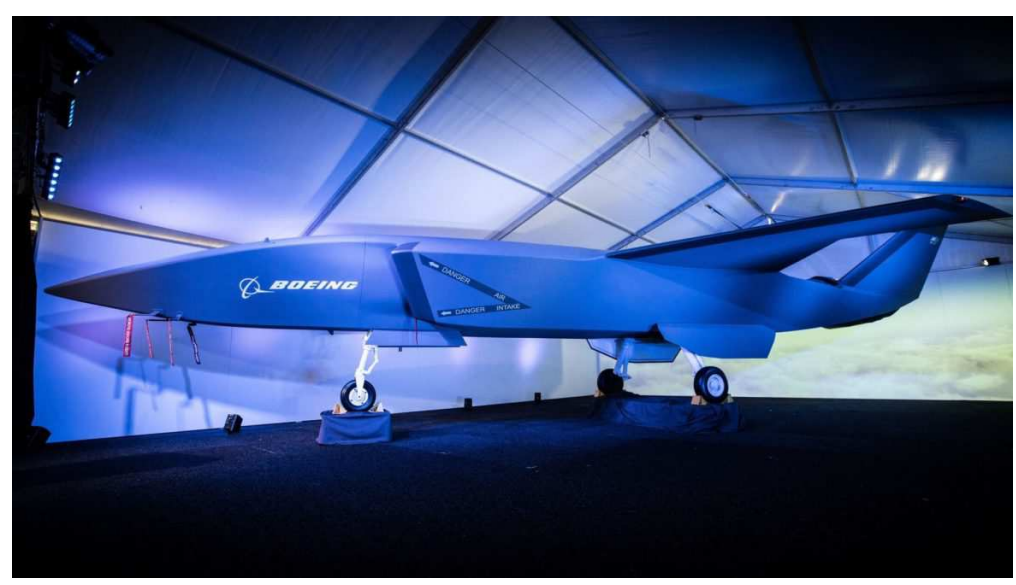

Fig. 1: Boeing airpower teaming system

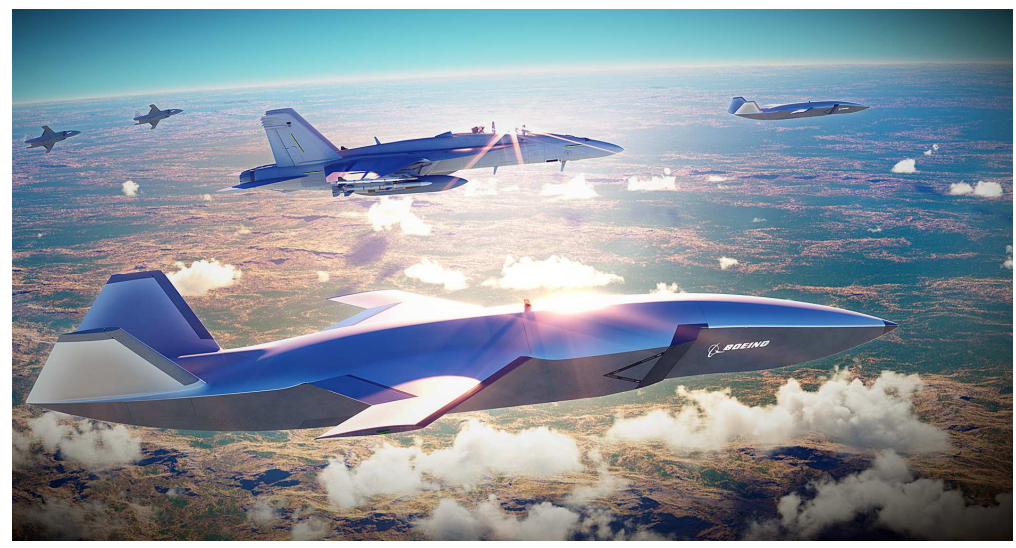

Fig. 2: Boeing airpower teaming system

Boeing, which manufactures commercial and military aircraft, wants to revolutionize the "art of war" and introduce a state-of-the-art, self-propelled aircraft into the battlefield to adapt to a variety of complex military missions.

They called it the Boeing Airpower Teaming System because it will team up well with military pilots during reconnaissance missions or even hostility or defensive missions (Fig. 1 and 2).

This autonomous airplane will play the role of additional help designed to significantly reduce the risks to which soldiers are often exposed.

The stand-alone aircraft can be sent both on reconnaissance missions and for attack operations (either for defense or for the removal of targets considered terrorist). He will be able to intercept the enemy in good time and to annihilate it.

It will be manufactured in Australia, it will have a length of more than $11 \mathrm{~m}$ and Boeing promises autonomy of over 3,700 kilometers (2,000 nautical miles).

Obviously, the company will not only produce for Americans or Australians. Any government will be able to purchase the autonomous airplane if it allows it (at least theoretically, because sales of such products are basically also with special political agreements).

It is very likely that in the future, we will not even have much need for soldiers if the missions are carried out by autonomous airplanes or robots. Good news, as democracies have come to pay citizens to motivate them to become soldiers.

\section{Results}

The Rockwell B-1 Lancer is a supersonic fourengine, variable geometry, a strategically used bomber by US Air Force (USAF). Following a competition, in 1970, the North American Rockwell B-1A was selected for the USAF program of a Mach 2 supersonic bomber with a range and payload to replace the Boeing B- 52 Stratofortress and XB-70 (which was abandoned). It was later developed as B-1B, first of all, a low-level, long-range penetrator and Mach 1.25 speed (high altitude speed capacity), the reduced speed is due to the modification of the engine air intakes to reduce the radar signature (Fig. 3). 


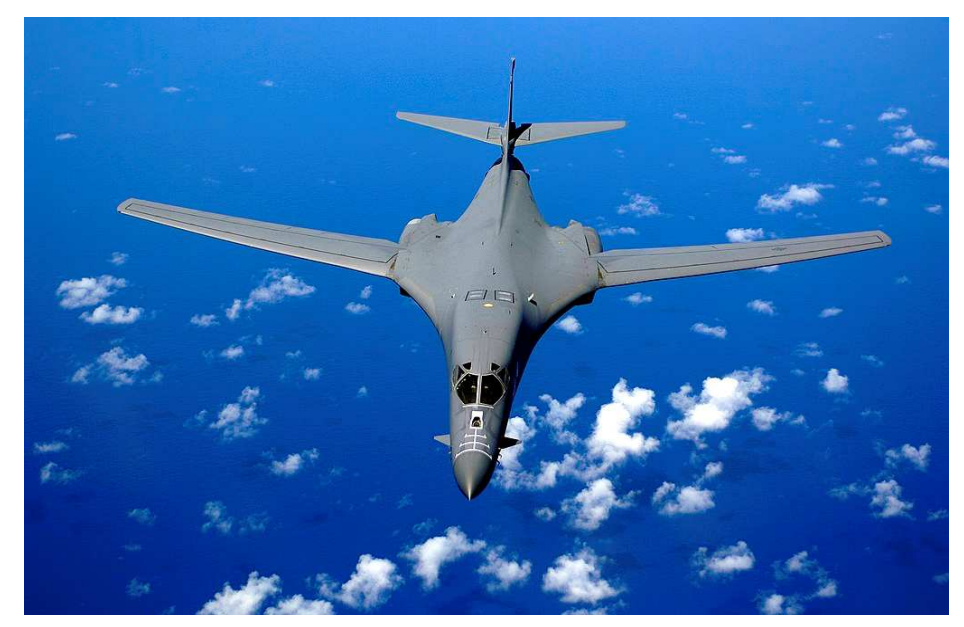

Fig. 3: A B1 Lancer

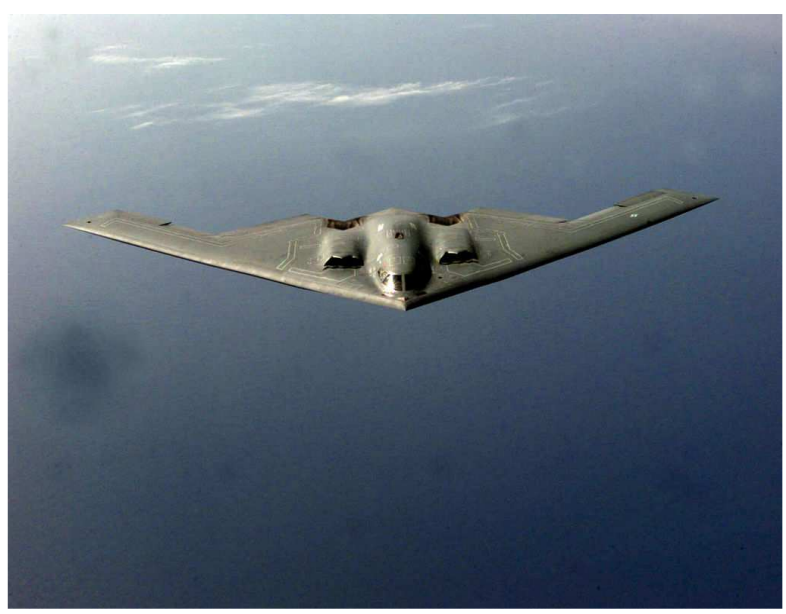

Fig. 4: Boeing B-2 Spirit is a strategically American stealth bomber that can launch both regular bombs and nuclear bombs

Boeing B-2 Spirit is a strategically American stealth bomber that can launch both regular bombs and nuclear bombs. It is built by Northrop Grumman and is the most expensive plane ever built in the world.

In the early $1980 \mathrm{~s}$, the Soviet Union introduced a new generation of Sukhoi Su-27 hunting/intercepting aircraft, Mikoyan-Gurevich MiG-29 and especially Mikoyan-Gurevich MiG-31, along with early warning and airplane sightings type BERIEV A-50. All these planes have down/shoot down capabilities to detect, track and attack targets under the radar horizon. Thus, the tactics used by the US B-52 bombers and the B-1 prototypes to penetrate the enemy space flying at very low altitudes under the terrestrial and air radar detection has become risky.

With the development by Northrop of the software called continuous curvature to measure the reflection of radar waves on round surfaces (see Tacit Blue), it was possible to design a heavily detectable aircraft with a much lower aerodynamic coefficient than at F-117.

The concept of a strategic bomber able to penetrate unplanned Soviet airspace emerged in the late 1970s (Fig. 4).

The idea was for the plane to enter the early hours of a nuclear war in the Soviet airspace without the risk of being detected by radar means or sensors in infrared. It was tasked to seek and destroy targets of maximum importance such as the Soviet Mobile Missile Missiles (SS-25), command and control centers and to create large breaches in the Soviet antiaircraft defense system. Thus, the easily detectable B52 and B-1 bombers would have been given a free passage to attack strategic targets that could not have come close to other conditions.

The specification provided for a passive electronic sweep and low interceptor multimode radar that is coupled to an inertial and GPS satellite navigation system for high-precision weapon guidance (Very low radar and infrared signature fuselage) and Intercontinental action line (including refueling capacity in flight) and capability to carry the full range of conventional and nuclear weapons.

It's the first fully engineered plane on the computer, inventing hundreds of new materials, new design, testing and computer-assisted manufacturing processes. It required extensive computer testing of all aerodynamic and radar signature features.

Very low radar detection required the choice of a fly-wing configuration (see Northrop YB-49). However, the aerodynamic instability of this configuration must always be compensated by a flyby-wire computerized flight control system. For this plane to fly and carry out the mission, it takes approx. 200 computers with specific tasks. 


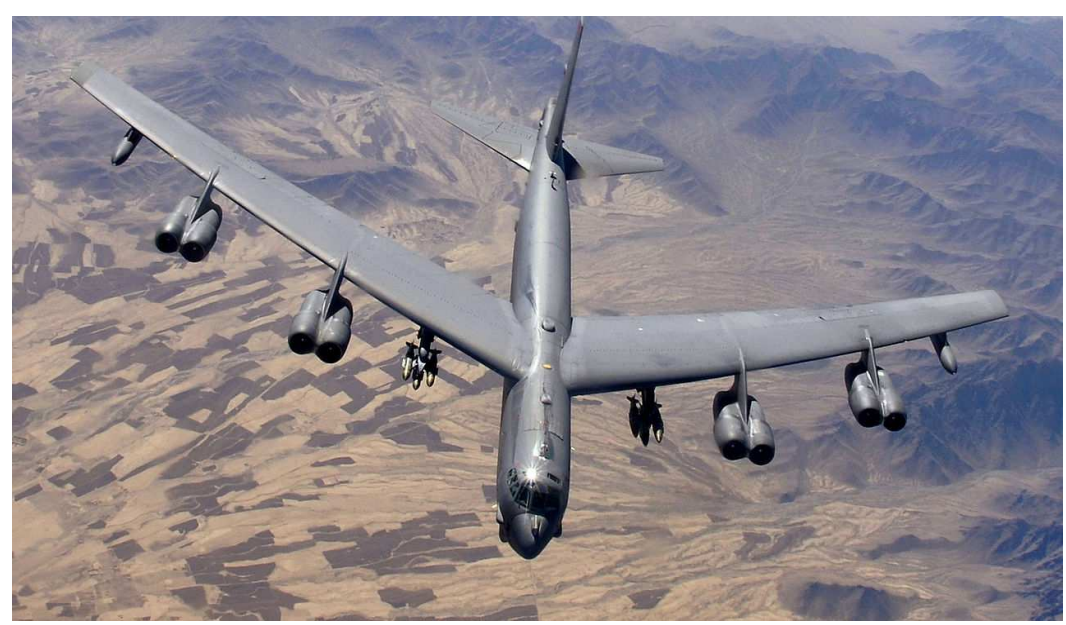

Fig. 5: Boeing B-52 Stratofortress is a long-range, subsonic, reaction-packed bomber

R\&D costs amounted to approx. \$46 billion.

Boeing B-52 Stratofortress is a long-range, subsonic, long-range reaction bomber. The B-52 was designed and built by Boeing, which subsequently provided maintenance and improvements. The bomber is used by the United States Air Force in the 1950s. It can carry up to 32 tons of weaponry.

After winning the contract in June 1946, the bomber evolved from a right-wing configuration and six turbo propellers to an arrow wing configuration and eight turbochargers for the YB-52 final prototype (Fig. 5). The inaugural flight took place in April 1952. Built to carry nuclear weapons in Cold War disaster missions, the B-52 Stratofortress replaced the Convair B-36. Although it has been used in many wars, the B-52 only used conventional weaponry in combat. The name Stratofortress is rarely used outside of official contexts; crews use the name BUFF (Big Ugly Fat/Flying Fucker/Fellow).

The B-52 has been in the United States arsenal since 1955. With superior performance at high subsonic speeds and relatively low operating costs, the B-52 has been retained despite the emergence of more advanced models such as North American XB-70 Valkyrie (capable of touching Mach 3), Rockwell B-1 Lancer (variable geometry) or Northrop Grumman B-2 Spirit (with stealth technology: undetectable radar).

\section{Discussion}

Military airplanes are constantly being renewed, bringing new models capable of changing the face of military actions, but also strategies and future action, thanks to new, increasingly advanced technologies that are continually being deployed. Airplanes have increased autonomy, increased combat capabilities and electronics and automation that are already taking on an SF movie. Today the military technique has often surpassed the limits of the SF becoming the reality louder than the fiction. Obviously, the most advanced military techniques are generally not disclosed to us, but we still hear a little about them or their capabilities from various sources of mass information.

\section{Conclusion}

Boeing will build a self-propelled military aircraft to accompany US combat aircraft during missions.

Boeing's autonomous airplane will achieve superior flying performance to those pilots even with the most modern aircraft.

If technology advances and becomes more accessible to civilians, why would not this happen in the military domain? US, Russian, Australian and British armies have already been using advanced technology for decades were civilians just dream, these technologies being totally secret and forbidden to the general public and mass media.

Boeing, which manufactures commercial and military aircraft, wants to revolutionize the "art of war" and introduce a state-of-the-art, self-propelled aircraft into the battlefield to adapt to a variety of complex military missions. They called it the Boeing Airpower Teaming System because it will team up well with military pilots during reconnaissance missions or even hostility or defensive missions.

This autonomous airplane will play the role of additional help designed to significantly reduce the risks to which soldiers are often exposed. The standalone aircraft can be sent both on reconnaissance missions and for attack operations (either for defense or for the removal of targets considered terrorist). He will be able to intercept the enemy in good time and to annihilate it. It will be manufactured in Australia and it will have a length of more than $11 \mathrm{~m}$ and Boeing promises autonomy of over 3,700 kilometers $(2,000$ nautical miles). 


\section{Acknowledgement}

The work was appreciated by teams of professors from the departments of automobiles from several universities in Romania and Italy. This text was acknowledged and appreciated by Associate Professor Aniello Riccio SECONDA UNIVERSITA' DEGLI STUDI DI NAPOLI Italy, whom we thanks and in this way.

\section{Funding Information}

Research contract: Contract number 36-5-4D/1986 from 24IV1985, beneficiary CNST RO (Romanian National Center for Science and Technology) Improving dynamic mechanisms internal combustion engines. All these matters are copyrighted. Copyrights: 548cgiywDssin, from: 22-04-2010, 08:48:48.

\section{Ethics}

Author declares that are not ethical issues that may arise after the publication of this manuscript. This article is original and contains unpublished material.

\section{References}

Ab-Rahman, M.S., H. Guna, MH. Harun, SD. Zan and K. Jumari, 2009. Cost-effective fabrication of self-made $1 \times 12$ polymer optical fiber-based optical splitters for automotive application. Am. J. Eng. Applied Sci., 2: 252-259. DOI: 10.3844/ajeassp.2009.252.259

Abam, F.I., I.U. Ugot and D.I. Igbong, 2012. Performance analysis and components irreversibilities of a $(25$ MW) gas turbine power plant modeled with a spray cooler. Am. J. Eng. Applied Sci., 5: 35-41.

DOI: $10.3844 /$ ajeassp.2012.35.41

Abdelkrim, H., S.B. Othman, A.K.B. Salem and S.B. Saoud, 2012. Dynamic partial reconfiguration contribution on system on programmable chip architecture for motor drive implementation. Am. J. Eng. Applied Sci., 5: 15-24.

DOI: 10.3844 /ajeassp.2012.15.24

Abdullah, M.Z., A. Saat and Z. Hamzah, 2011. Optimization of energy dispersive $\mathrm{x}$-ray fluorescence spectrometer to analyze heavy metals in moss samples. Am. J. Eng. Applied Sci., 4: 355-362. DOI: 10.3844/ajeassp.2011.355.362

Abdullah, M., A. F.M. Zain, Y. H. Ho and S. Abdullah, 2009. TEC and scintillation study of equatorial ionosphere: A month campaign over sipitang and Parit Raja stations, Malaysia. Am. J. Eng. Applied Sci., 2: 44-49. DOI: 10.3844/ajeassp.2009.44.49

Abdullah, H. and S.A. Halim, 2009. Electrical and magnetoresistive studies $\mathrm{Nd}$ doped on La-Ba-Mn-O manganites for low-field sensor application. Am. J. Eng. Applied Sci., 2: 297-303.

DOI: 10.3844/ajeassp.2009.297.303
Abouobaida, H., 2016. Robust and efficient controller to design a standalone source supplied DC and AC load powered by photovoltaic generator. Am. J. Eng. Applied Sci., 9: 894-901.

DOI: 10.3844 /ajeassp.2016.894.901

Abu-Ein, S., 2009. Numerical and analytical study of exhaust gases flow in porous media with applications to diesel particulate filters. Am. J. Eng. Applied Sci., 2: 70-75.

DOI: 10.3844/ajeassp.2009.70.75

Abu-Lebdeh, T.M., G. Pérez-de León, S.A. Hamoush, R.D. Seals and V.E. Lamberti, 2016. Gas atomization of molten metal: Part II. Applications. Am. J. Eng. Applied Sci., 9: 334-349. DOI: 10.3844 /ajeassp.2016.334.349

Agarwala, S., 2016. A perspective on 3D bioprinting technology: Present and future. Am. J. Eng. Applied Sci., 9: 985-990. DOI: 10.3844/ajeassp.2016.985.990

Ahmed, M., R. Khan, M. Billah and S. Farhana, 2010. A novel navigation algorithm for hexagonal hexapod robot. Am. J. Eng. Applied Sci., 3: 320-327.

DOI: 10.3844 /ajeassp.2010.320.327

Ahmed, R., M. Khan, H. Haque and H. Rahman, 2016. An approach to develop a dynamic job shop scheduling by fuzzy rule-based system and comparative study with the traditional priority rules. Am. J. Eng. Applied Sci., 9: 202-212. DOI: 10.3844/ajeassp.2016.202.212

Akhesmeh, S., N. Pourmahmoud and H. Sedgi, 2008. Numerical study of the temperature separation in the ranque-hilsch vortex tube. Am. J. Eng. Applied Sci., 1: 181-187. DOI: 10.3844/ajeassp.2008.181.187

Al-Abbas, I.K., 2009. Reduced order models of a current source inverter induction motor drive. Am. J. Eng. Applied Sci., 2: 39-43. DOI: 10.3844/ajeassp.2009.39.43

Al-Hasan, M.I. and A.S. Al-Ghamdi, 2016. Energy balance for a diesel engine operates on a pure biodiesel, diesel fuel and biodiesel-diesel blends. Am. J. Eng. Applied Sci., 9: 458-465. DOI: 10.3844 /ajeassp.2016.458.465

Al Smadi, T.A., 2011. Low cost smart sensor design. Am. J. Eng. Applied Sci., 4: 162-168. DOI: 10.3844 /ajeassp.2011.162.168

AL Qadi, A.N.S., M.B.A. ALhasanat, A. AL Dahamsheh and S. AL Zaiydneen, 2016a. Using of box-benken method to predict the compressive strength of selfcompacting concrete containing Wadi Musa Bentonite, Jordan. Am. J. Eng. Applied Sci., 9: 406-411. DOI: 10.3844/ajeassp.2016.406.411

Al Qadi, A.N.S., M.B.A. Alhasanat and M. Haddad, 2016b. Effect of crumb rubber as coarse and fine aggregates on the properties of asphalt concrete. Am. J. Eng. Applied Sci., 9: 558-564. DOI: 10.3844 /ajeassp.2016.558.564 
Aleksic, S. and A. Lovric, 2011. Energy consumption and environmental implications of wired access networks. Am. J. Eng. Applied Sci., 4: 531-539. DOI: 10.3844 /ajeassp.2011.531.539

Alhasanat, M.B., A.N. Al Qadi, O.A. Al Khashman and A. Dahamsheh, 2016. Scanning electron microscopic evaluation of self-compacting concrete spalling at elevated temperatures. Am. J. Eng. Applied Sci., 9: 119-127. DOI: 10.3844/ajeassp.2016.119.127

Ali, K.S. and J.L. Shumaker, 2013. Hardware in the loop simulator for multi-agent unmanned aerial vehicles environment. Am. J. Eng. Applied Sci., 6: 172-177. DOI: 10.3844/ajeassp.2013.172.177

Ali, G.A.M., O. Fouad and S.A. Makhlouf, 2016. Electrical properties of cobalt oxide/silica nanocomposites obtained by sol-gel technique. Am. J. Eng. Applied Sci., 9: 12-16. DOI: 10.3844/ajeassp.2016.12.16

Alwetaishi, M.S., 2016. Impact of building function on thermal comfort: A review paper. Am. J. Eng. Applied Sci., 9: 928-945.

DOI: 10.3844/ajeassp.2016.928.945

Aly, W.M. and M.S. Abuelnasr, 2010. Electronic design automation using object oriented electronics. Am. J. Eng. Applied Sci., 3: 121-127. DOI: 10.3844/ajeassp.2010.121.127

Amani, N., 2016. Design and implementation of optimum management system using cost evaluation and financial analysis for prevention of building failure. Am. J. Eng. Applied Sci., 9: 281-296.

DOI: 10.3844/ajeassp.2016.281.296

Anizan, S., K. Yusri, C.S. Leong, N. Amin and S. Zaidi et al., 2011. Effects of the contact resistivity variations of the screen-printed silicon solar cell. Am. J. Eng. Applied Sci., 4: 328-331. DOI: 10.3844/ajeassp.2011.328.331

Ascione, F., N. Bianco, R.F. De Masi, F. de Rossi and C. De Stasio et al., 2016b. Energy audit of health care facilities: Dynamic simulation of energy performances and energy-oriented refurbishment of system and equipment for microclimatic control. Am. J. Eng. Applied Sci., 9: 814-834.

DOI: 10.3844/ajeassp.2016.814.834

Augustine, A., R.D. Prakash, R. Xavier and M.C. Parassery, 2016. Review of signal processing techniques for detection of power quality events. Am. J. Eng. Applied Sci., 9: 364-370. DOI: 10.3844/ajeassp.2016.364.370

Aversa, R., R.V.V. Petrescu, A. Apicella and F.I.T. Petrescu, 2017a. Nano-diamond hybrid materials for structural biomedical application. Am. J. Biochem. Biotechnol., 13: 34-41.

DOI: $10.3844 /$ ajbbsp.2017.34.41

Aversa, R., D. Parcesepe, R.V.V. Petrescu, F. Berto and G. Chen et al., 2017b. Process ability of bulk metallic glasses. Am. J. Applied Sci., 14: 294-301. DOI: 10.3844/ajassp.2017.294.301
Aversa, R., F.I.T. Petrescu, R.V. Petrescu and A. Apicella, 2016a. Biomimetic FEA bone modeling for customized hybrid biological prostheses development. Am. J. Applied Sci., 13: 1060-1067. DOI: 10.3844/ajassp.2016.1060.1067

Aversa, R., D. Parcesepe, R.V. Petrescu, G. Chen and F.I.T. Petrescu et al., 2016b. Glassy amorphous metal injection molded induced morphological defects. Am. J. Applied Sci., 13: 1476-1482. DOI: 10.3844 /ajassp.2016.1476.1482

Aversa, R., R.V. Petrescu, F.I.T. Petrescu and A. Apicella, 2016c. Smart-factory: Optimization and process control of composite centrifuged pipes. Am. J. Applied Sci., 13: 1330-1341. DOI: 10.3844/ajassp.2016.1330.1341

Aversa, R., F. Tamburrino, R.V. Petrescu, F.I.T. Petrescu and M. Artur et al., $2016 \mathrm{~d}$. Biomechanically inspired shape memory effect machines driven by muscle like acting NiTi alloys. Am. J. Applied Sci., 13: 1264-1271. DOI: 10.3844/ajassp.2016.1264.1271

Aversa, R., E.M. Buzea, R.V. Petrescu, A. Apicella and M. Neacsa et al., 2016e. Present a mechatronic system having able to determine the concentration of carotenoids. Am. J. Eng. Applied Sci., 9: 1106-1111. DOI: 10.3844/ajeassp.2016.1106.1111

Aversa, R., R.V. Petrescu, R. Sorrentino, F.I.T. Petrescu and A. Apicella, 2016f. Hybrid ceramo-polymeric nanocomposite for biomimetic scaffolds design and preparation. Am. J. Eng. Applied Sci., 9: 1096-1105. 10.3844/ajeassp.2016.1096.1105

Aversa, R., V. Perrotta, R.V. Petrescu, C. Misiano and F.I.T. Petrescu et al., 2016g. From structural colors to super-hydrophobicity and achromatic transparent protective coatings: Ion plating plasma assisted $\mathrm{TiO}_{2}$ and $\mathrm{SiO}_{2}$ Nano-film deposition. Am. J. Eng. Applied Sci., 9: 1037-1045.

DOI: 10.3844/ajeassp.2016.1037.1045

Aversa, R., R.V. Petrescu, F.I.T. Petrescu and A. Apicella, 2016h. Biomimetic and Evolutionary Design Driven Innovation in Sustainable Products Development. Am. J. Eng. Applied Sci., 9: 1027-1036. DOI: 10.3844/ajeassp.2016.1027.1036

Aversa, R., R.V. Petrescu, A. Apicella and F.I.T. Petrescu, 2016i. Mitochondria are naturally micro robots-a review. Am. J. Eng. Applied Sci., 9: 991-1002.

Aversa, R., R.V. Petrescu, A. Apicella and F.I.T. Petrescu, 2016j. We are addicted to vitamins C and EA review. Am. J. Eng. Applied Sci., 9: 1003-1018. DOI: 10.3844/ajeassp.2016.1003.1018

Aversa, R., R.V. Petrescu, A. Apicella and F.I.T. Petrescu, 2016k. Physiologic human fluids and swelling behavior of hydrophilic biocompatible hybrid ceramo-polymeric materials. Am. J. Eng. Applied Sci., 9: 962-972.

DOI: 10.3844/ajeassp.2016.962.972 
Aversa, R., R.V. Petrescu, A. Apicella and F.I.T. Petrescu, 20161. One can slow down the aging through antioxidants. Am. J. Eng. Applied Sci., 9: 1112-1126. DOI: 10.3844/ajeassp.2016.1112.1126

Aversa, R., R.V. Petrescu, A. Apicella and F.I.T. Petrescu, 2016m. About homeopathy or «Similia similibus curentur $\gg$. Am. J. Eng. Applied Sci., 9: 1164-1172. DOI: 10.3844/ajeassp.2016.1164.1172

Aversa, R., R.V. Petrescu, A. Apicella and F.I.T. Petrescu, 2016n. The basic elements of life's. Am. J. Eng. Applied Sci., 9: 1189-1197.

DOI: 10.3844/ajeassp.2016.1189.1197

Aversa, R., F.I.T. Petrescu, R.V. Petrescu and A. Apicella, 2016o. Flexible stem trabecular prostheses. Am. J. Eng. Applied Sci., 9: 1213-1221. DOI: 10.3844/ajeassp.2016.1213.1221

Babayemi, A.K., 2016. Thermodynamics, non-linear isotherms, statistical modeling and optimization of phosphorus adsorption from wastewater. Am. J. Eng. Applied Sci., 9: 1019-1026.

DOI: 10.3844/ajeassp.2016.1019.1026

Bakar, R.A., M.K. Mohammed and M.M. Rahman, 2009. Numerical study on the performance characteristics of hydrogen fueled port injection internal combustion engine. Am. J. Eng. Applied Sci., 2: 407-415.

DOI: 10.3844/ajeassp.2009.407.415

Barone, G., A. Buonomano, C. Forzano and A. Palombo, 2016. WLHP systems in commercial buildings: A case study analysis based on a dynamic simulation approach. Am. J. Eng. Applied Sci., 9: 659-668. DOI: 10.3844/ajeassp.2016.659.668

Bedon, C., 2016. Review on the use of FRP composites for facades and building skins. Am. J. Eng. Applied Sci., 9: 713-723.

DOI: 10.3844 /ajeassp.2016.713.723

Bedon, C. and C. Amadio, 2016. A unified approach for the shear buckling design of structural glass walls with non-ideal restraints. Am. J. Eng. Applied Sci., 9: 64-78. DOI: 10.3844/ajeassp.2016.64.78

Bedon, C. and C. Louter, 2016. Finite-element numerical simulation of the bending performance of posttensioned structural glass beams with adhesively bonded CFRP tendons. Am. J. Eng. Applied Sci., 9: 680-691. DOI: 10.3844/ajeassp.2016.680.691

Bolonkin, A., 2009a. Femtotechnology: Nuclear matter with fantastic properties. Am. J. Eng. Applied Sci., 2: 501-514. DOI: 10.3844/ajeassp.2009.501.514

Bolonkin, A., 2009b. Converting of matter to nuclear energy by ab-generator. Am. J. Eng. Applied Sci., 2: 683-693. DOI: 10.3844/ajeassp.2009.683.693

Boucetta, A., 2008. Vector control of a variable reluctance machine stator and rotor discs imbricates. Am. J. Eng. Applied Sci., 1: 260-265.

DOI: 10.3844 /ajeassp.2008.260.265
Bucinell, R.B., 2016. Stochastic model for variable amplitude fatigue induced delamination growth in graphite/epoxy laminates. Am. J. Eng. Applied Sci., 9: 635-646.

DOI: $10.3844 /$ ajeassp.2016.635.646

Budak, S., Z. Xiao, B. Johnson, J. Cole and M. Drabo et al., 2016. Highly-efficient advanced thermoelectric devices from different multilayer thin films. Am. J. Eng. Applied Sci., 9: 356-363. DOI: 10.3844/ajeassp.2016.356.363

Buonomano, A., F. Calise and M. Vicidomini, 2016a. A novel prototype of a small-scale solar power plant: Dynamic simulation and thermoeconomic analysis. Am. J. Eng. Applied Sci., 9: 770-788. DOI: 10.3844/ajeassp.2016.770.788

Buonomano, A., F. Calise, M.D. d'Accadia, R. Vanoli and M. Vicidomini, 2016b. Simulation and experimental analysis of a demonstrative solar heating and cooling plant installed in Naples (Italy). Am. J. Eng. Applied Sci., 9: 798-813. DOI: 10.3844 ajeassp.2016.798.813

Calise, F., M.D. dâ' Accadia, L. Libertini, E. Quiriti and M. Vicidomini, 2016. Dynamic simulation and optimum operation strategy of a trigeneration system serving a hospital. Am. J. Eng. Applied Sci., 9: 854-867. DOI: 10.3844/ajeassp.2016.854.867

Campo, T., M. Cotto, F. Marquez, E. Elizalde and C. Morant, 2016. Graphene synthesis by plasmaenhanced CVD growth with ethanol. Am. J. Eng. Applied Sci., 9: 574-583.

DOI: 10.3844 /ajeassp.2016.574.583

Cardu, M., P. Oreste and T. Cicala, 2009. Analysis of the tunnel boring machine advancement on the bologna-florence railway link. Am. J. Eng. Applied Sci., 2: 416-420.

DOI: 10.3844/ajeassp.2009.416.420

Chen, G. and L. Xu, 2016. A general strategy to enhance upconversion luminescence in rare-earth-ion-doped oxide nanocrystals. Am. J. Eng. Applied Sci., 9: 79-83. DOI: 10.3844/ajeassp.2016.79.83

Chiozzi, A., G. Milani, N. Grillanda and A. Tralli, 2016. An adaptive procedure for the limit analysis of FRP reinforced masonry vaults and applications. Am. J. Eng. Applied Sci., 9: 735-745.

DOI: 10.3844/ajeassp.2016.735.745

Chisari, C. and C. Bedon, 2016. Multi-objective optimization of FRP jackets for improving the seismic response of reinforced concrete frames. Am. J. Eng. Applied Sci., 9: 669-679. DOI: 10.3844/ajeassp.2016.669.679

Darabi, A., S.A. Soleamani and A. Hassannia, 2008. Fuzzy based digital automatic voltage regulator of a synchronous generator with unbalanced loads. Am. J. Eng. Applied Sci., 1: 280-286. DOI: 10.3844 /ajeassp.2008.280.286 
Daud, H., N. Yahya, A.A. Aziz and M.F. Jusoh, 2008. Development of wireless electric concept powering electrical appliances. Am. J. Eng. Applied Sci., 1: 12-15. DOI: 10.3844/ajeassp.2008.12.15

Djalel, D., M. Mourad and H. Labar, 2013. New approach of electromagnetic fields of the lightning discharge. Am. J. Eng. Applied Sci., 6: 369-383. DOI: 10.3844/ajeassp.2013.369.383

dos Santos, F.A. and C. Bedon, 2016. Preliminary experimental and finite-element numerical assessment of the structural performance of SMAreinforced GFRP systems. Am. J. Eng. Applied Sci., 9: 692-701. DOI: 10.3844/ajeassp.2016.692.701

Ebrahim, N.A., S. Ahmed, S.H.A. Rashid and Z. Taha, 2012. Technology use in the virtual R\&D teams. Am. J. Eng. Applied Sci., 5: 9-14. DOI: 10.3844/ajeassp.2012.9.14

El-Labban, H.F., M. Abdelaziz and E.R.I. Mahmoud, 2013. Modification of carbon steel by laser surface melting: Part I: Effect of laser beam travelling speed on microstructural features and surface hardness. Am. J. Eng. Applied Sci., 6: 352-359. DOI: 10.3844/ajeassp.2013.352.359

Elliott, A., S. AlSalihi, A.L. Merriman and M.M. Basti, 2016. Infiltration of nanoparticles into porous binder jet printed parts. Am. J. Eng. Applied Sci., 9: 128-133. DOI: 10.3844/ajeassp.2016.128.133

Elmeddahi, Y., H. Mahmoudi, A. Issaadi, M.F.A. Goosen and R. Ragab, 2016b. Evaluating the effects of climate change and variability on water resources: A case study of the cheliff basin in Algeria. Am. J. Eng. Applied Sci., 9: 835-845. DOI: 10.3844/ajeassp.2016.835.845

El-Tous, Y., 2008. Pitch angle control of variable speed wind turbine. Am. J. Eng. Applied Sci., 1: 118-120. DOI: 10.3844/ajeassp.2008.118.120

Faizal, A., S. Mulyono, R. Yendra and A. Fudholi, 2016. Design Maximum Power Point Tracking (MPPT) on photovoltaic panels using fuzzy logic method. Am. J. Eng. Applied Sci., 9: 789-797. DOI: $10.3844 /$ ajeassp.2016.789.797

Farahani, A.S., N.M. Adam and M.K.A. Ariffin, 2010. Simulation of airflow and aerodynamic forces acting on a rotating turbine ventilator. Am. J. Eng. Applied Sci., 3: 159-170.

DOI: 10.3844 /ajeassp.2010.159.170

Fathallah, A.Z.M. and R.A. Bakar, 2009. Prediction studies for the performance of a single cylinder high speed spark ignition linier engine with spring mechanism as return cycle. Am. J. Eng. Applied Sci., 2: 713-720. DOI: 10.3844/ajeassp.2009.713.720

Fen, Y.W., W.M.M. Yunus, M.M. Moksin, Z.A. Talib and N.A. Yusof, 2011. Optical properties of crosslinked chitosan thin film with glutaraldehyde using surface Plasmon resonance technique. Am. J. Eng. Applied Sci., 4: 61-65. DOI: 10.3844/ajeassp.2011.61.65
Feraga, C.E., A. Moussaoui, A. Bouldjedri and A. Yousfi, 2009. Robust position controller for a permanent magnet synchronous actuator. Am. J. Eng. Applied Sci., 2: 388-392. DOI: 10.3844 /ajeassp.2009.388.392

Gusti, A.P. and Semin, 2016. The effect of vessel speed on fuel consumption and exhaust gas emissions. Am. J. Eng. Applied Sci., 9: 1046-1053. DOI: 10.3844 /ajeassp.2016.1046.1053

Hassan, M., H. Mahjoub and M. Obed, 2012. Voicebased control of a DC servo motor. Am. J. Eng. Applied Sci., 5: 89-92. DOI: 10.3844/ajeassp.2012.89.92

Hasan, S. and M.H. El-Naas, 2016. Optimization of a combined approach for the treatment of carbide slurry and capture of $\mathrm{CO}_{2}$. Am. J. Eng. Applied Sci., 9: 449-457. DOI: 10.3844/ajeassp.2016.449.457

Helmy, A.K. and G.S. El-Taweel, 2010. Neural network change detection model for satellite images using textural and spectral characteristics. Am. J. Eng. Applied Sci., 3: 604-610. DOI: 10.3844 /ajeassp.2010.604.610

Hirun, W., 2016. Evaluation of interregional freight generation modelling methods by using nationwide commodity flow survey data. Am. J. Eng. Applied Sci., 9: 625-634.

DOI: 10.3844/ajeassp.2016.625.634

Ho, C.Y.F., B.W.K. Ling, S.G. Blasi, Z.W. Chi and W.C. Siu, 2011. Single step optimal block matched motion estimation with motion vectors having arbitrary pixel precisions. Am. J. Eng. Applied Sci., 4: 448-460. DOI: 10.3844/ajeassp.2011.448.460

Huang, B., S.H. Masood, M. Nikzad, P.R. Venugopal and A. Arivazhagan, 2016. Dynamic mechanical properties of fused deposition modelling processed polyphenylsulfone material. Am. J. Eng. Applied Sci., 9: 1-11. DOI: 10.3844/ajeassp.2016.1.11

Idarwazeh, S., 2011. Inverse discrete Fourier transformdiscrete Fourier transform techniques for generating and receiving spectrally efficient frequency division multiplexing signals. Am. J. Eng. Applied Sci., 4: 598-606. DOI: 10.3844/ajeassp.2011.598.606

Iqbal, M., 2016. An overview of Energy Loss Reduction (ELR) software used in Pakistan by WAPDA for calculating transformer overloading, line losses and energy losses. Am. J. Eng. Applied Sci., 9: 442-448. DOI: 10.3844/ajeassp.2016.442.448

Ismail, M.I.S., Y. Okamoto, A. Okada and Y. Uno, 2011. Experimental investigation on micro-welding of thin stainless steel sheet by fiber laser. Am. J. Eng. Applied Sci., 4: 314-320. DOI: 10.3844 /ajeassp.2011.314.320

Jaber, A.A. and R. Bicker, 2016. Industrial robot fault detection based on statistical control chart. Am. J. Eng. Applied Sci., 9: 251-263.

DOI: 10.3844/ajeassp.2016.251.263 
Jafari, N., A. Alsadoon, C.P. Withana, A. Beg and A. Elchouemi, 2016. Designing a comprehensive security framework for smartphones and mobile devices. Am. J. Eng. Applied Sci., 9: 724-734.

DOI: 10.3844/ajeassp.2016.724.734

Jalil, M.I.A. and J. Sampe, 2013. Experimental investigation of thermoelectric generator modules with different technique of cooling system. Am. J. Eng. Applied Sci., 6: 1-7. DOI: 10.3844/ajeassp.2013.1.7

Jaoude, A.A. and K. El-Tawil, 2013. Analytic and nonlinear prognostic for vehicle suspension systems. Am. J. Eng. Applied Sci., 6: 42-56.

DOI: 10.3844/ajeassp.2013.42.56

Jarahi, H., 2016. Probabilistic seismic hazard deaggregation for Karaj City (Iran). Am. J. Eng. Applied Sci., 9: 520-529. DOI: 10.3844/ajeassp.2016.520.529

Jarahi, H. and S. Seifilaleh, 2016. Rock fall hazard zonation in haraz highway. Am. J. Eng. Applied Sci., 9: 371-379. DOI: 10.3844/ajeassp.2016.371.379

Jauhari, K., A. Widodo and I. Haryanto, 2016. Identification of a machine tool spindle critical frequency through modal and imbalance response analysis. Am. J. Eng. Applied Sci., 9: 213-221.

DOI: 10.3844/ajeassp.2016.213.221

Jiang, J., Q. Chen and S. Nimbalkar, 2016. Field data based method for predicting long-term settlements. Am. J. Eng. Applied Sci., 9: 466-476.

DOI: 10.3844/ajeassp.2016.466.476

Kaewnai, S. and S. Wongwises, 2011. Improvement of the runner design of Francis turbine using computational fluid dynamics. Am. J. Eng. Applied Sci., 4: 540-547.

DOI: $10.3844 /$ ajeassp.2011.540.547

Kamble, V.G. and N. Kumar, 2016. Fabrication and tensile property analysis of polymer matrix composites of graphite and silicon carbide as fillers. Am. J. Eng. Applied Sci., 9: 17-30. DOI: 10.3844/ajeassp.2016.17.30

Kazakov, V.V., V.I. Yusupov, V.N. Bagratashvili, A.I. Pavlikov and V.A. Kamensky, 2016. Control of bubble formation at the optical fiber tip by analyzing ultrasound acoustic waves. Am. J. Eng. Applied Sci., 9: 921-927.

DOI: 10.3844/ajeassp.2016.921.927

Kechiche, O.B.H.B., H.B.A. Sethom, H. Sammoud and I.S. Belkhodja, 2011. Optimized high-frequency signal injection based permanent magnet synchronous motor rotor position estimation applied to washing machines. Am. J. Eng. Applied Sci., 4: 390-399. DOI: 10.3844/ajeassp.2011.390.399

Kuli, I., T.M. Abu-Lebdeh, E.H. Fini and S.A. Hamoush, 2016. The use of nano-silica for improving mechanical properties of hardened cement paste. Am. J. Eng. Applied Sci., 9: 146-154. DOI: 10.3844/ajeassp.2016.146.154
Kunanoppadon, J., 2010. Thermal efficiency of a combined turbocharger set with gasoline engine. Am. J. Eng. Applied Sci., 3: 342-349. DOI: 10.3844/ajeassp.2010.342.349

Kwon, S., Y. Tani, H. Okubo and T. Shimomura, 2010. Fixed-star tracking attitude control of spacecraft using single-gimbal control moment gyros. Am. J. Eng. Applied Sci., 3: 49-55.

DOI: 10.3844 /ajeassp.2010.49.55

Lamarre, A., E.H. Fini and T.M. Abu-Lebdeh, 2016. Investigating effects of water conditioning on the adhesion properties of crack sealant. Am. J. Eng. Applied Sci., 9: 178-186. DOI: 10.3844 ajeassp.2016.178.186

Lubis, Z., A.N. Abdalla, Mortaza and R. Ghon, 2009. Mathematical modeling of the three phase induction motor couple to DC motor in hybrid electric vehicle. Am. J. Eng. Applied Sci., 2: 708-712. DOI: 10.3844 /ajeassp.2009.708.712

Madani, D.A.L. and A. Dababneh, 2016. Rapid entire body assessment: A literature review. Am. J. Eng. Applied Sci., 9: 107-118. DOI: 10.3844/ajeassp.2016.107.118

Malomar, G.E.B., A. Gueye, C. Mbow, V.B. Traore and A.C. Beye, 2016. Numerical study of natural convection in a square porous cavity thermally modulated on both side walls. Am. J. Eng. Applied Sci., 9: 591-598. DOI: 10.3844/ajeassp.2016.591.598

Mansour, M.A.A., 2016. Developing an anthropometric database for saudi students and comparing saudi dimensions relative to Turkish and Iranian peoples. Am. J. Eng. Applied Sci., 9: 547-557. DOI: 10.3844/ajeassp.2016.547.557

Marghany, M. and M. Hashim, 2009. Robust of doppler centroid for mapping sea surface current by using radar satellite data. Am. J. Eng. Applied Sci., 2: 781-788. DOI: 10.3844/ajeassp.2009.781.788

Martins, F.R., A.R. Gonçalves and E.B. Pereira, 2016. Observational study of wind shear in Northeastern Brazil. Am. J. Eng. Applied Sci., 9: 484-504. DOI: 10.3844/ajeassp.2016.484.504

Mavukkandy, M.O., S. Chakraborty, T. Abbasi and S.A. Abbasi, 2016. A clean-green synthesis of platinum nanoparticles utilizing a pernicious weed lantana (Lantana Camara). Am. J. Eng. Applied Sci., 9: 84-90. DOI: 10.3844/ajeassp.2016.84.90

Minghini, F., N. Tullini and F. Ascione, 2016. Updating Italian design guide CNR DT-205/2007 in view of recent research findings: Requirements for pultruded FRP profiles. Am. J. Eng. Applied Sci., 9: 702-712. DOI: 10.3844/ajeassp.2016.702.712

Moezi, N., D. Dideban and A. Ketabi, 2008. A novel integrated SET based inverter for nano power electronic applications. Am. J. Eng. Applied Sci., 1: 219-222. DOI: 10.3844/ajeassp.2008.219.222 
Mohamed, M.A., A.Y. Tuama, M. Makhtar, M.K. Awang and M. Mamat, 2016. The effect of RSA exponential key growth on the multi-core computational resource. Am. J. Eng. Applied Sci., 9: 1054-1061. DOI: 10.3844/ajeassp.2016.1054.1061

Mohan, K.S.R., P. Jayabalan and A. Rajaraman, 2012. Properties of fly ash based coconut fiber composite. Am. J. Eng. Applied Sci., 5: 29-34. DOI: 10.3844 /ajeassp.2012.29.34

Mohseni, E. and K.D. Tsavdaridis, 2016. Effect of nanoalumina on pore structure and durability of class $\mathrm{F}$ fly ash self-compacting mortar. Am. J. Eng. Applied Sci., 9: 323-333. DOI: 10.3844/ajeassp.2016.323.333

Momani, M.A., T.A. Al Smadi, FM. Al Taweel and K.A. Ghaidan, 2011. GPS ionospheric total electron content and scintillation measurements during the October 2003 magnetic storm. Am. J. Eng. Applied Sci., 4: 301-306.

DOI: 10.3844 /ajeassp.2011.301.306

Mondal, R., S. Sahoo and C.S. Rout, 2016. Mixed nickel cobalt manganese oxide nanorods for supercapacitor application. Am. J. Eng. Applied Sci., 9: 540-546. DOI: 10.3844/ajeassp.2016.540.546

Montgomery, J., T.M. Abu-Lebdeh, S.A. Hamoush and M. Picornell, 2016. Effect of nano-silica on the compressive strength of harden cement paste at different stages of hydration. Am. J. Eng. Applied Sci., 9: 166-177. DOI: 10.3844/ajeassp.2016.166.177

Morse, A., M.M. Mansfield, R.M. Alley, H.A. Kerr and R.B. Bucinell, 2016. Traction enhancing products affect maximum torque at the shoe-floor interface: A potential increased risk of ACL injury. Am. J. Eng. Applied Sci., 9: 889-893.

DOI: $10.3844 /$ ajeassp.2016.889.893

Moubarek, T. and A. Gharsallah, 2016. A six-port reflectometer calibration using Wilkinson power divider. Am. J. Eng. Applied Sci., 9: 274-280. DOI: 10.3844/ajeassp.2016.274.280

Nabilou, A., 2016a. Effect of parameters of selection and replacement drilling bits based on geo-mechanical factors: (case study: Gas and oil reservoir in the Southwest of Iran). Am. J. Eng. Applied Sci., 9: 380-395. DOI: 10.3844/ajeassp.2016.380.395

Nabilou, A., 2016b. Study of the parameters of Steam Assisted Gravity Drainage (SAGD) method for enhanced oil recovery in a heavy oil fractured carbonate reservoir. Am. J. Eng. Applied Sci., 9: 647-658. DOI: 10.3844/ajeassp.2016.647.658

Nachiengtai, T., W. Chim-Oye, S. Teachavorasinskun and W. Sa-Ngiamvibool, 2008. Identification of shear band using elastic shear wave propagation. Am. J. Eng. Applied Sci., 1: 188-191.

DOI: 10.3844 ajeassp.2008.188.191
Nahas, R. and S.P. Kozaitis, 2014. Metric for the fusion of synthetic and real imagery from multimodal sensors. Am. J. Eng. Applied Sci., 7: 355-362. DOI: 10.3844/ajeassp.2014.355.362

Nandhakumar, S., V. Selladurai and S. Sekar, 2009. Numerical investigation of an industrial robot arm control problem using haar wavelet series. Am. J. Eng. Applied Sci., 2: 584-589.

DOI: 10.3844 /ajeassp.2009.584.589

Ng, K.C., M.Z. Yusoff, K. Munisamy, H. Hasini and N.H. Shuaib, 2008. Time-marching method for computations of high-speed compressible flow on structured and unstructured grid. Am. J. Eng. Applied Sci., 1: 89-94.

DOI: 10.3844/ajeassp.2008.89.94

Obaiys, S.J., Z. Abbas, N.M.A. Nik Long, A.F. Ahmad and A. Ahmedov et al., 2016. On the general solution of first-kind hypersingular integral equations. Am. J. Eng. Applied Sci., 9: 195-201. DOI: 10.3844/ajeassp.2016.195.201

Odeh, S., R. Faqeh, L. Abu Eid and N. Shamasneh, 2009. Vision-based obstacle avoidance of mobile robot using quantized spatial model. Am. J. Eng. Applied Sci., 2: 611-619. DOI: 10.3844/ajeassp.2009.611.619

Opafunso, Z.O., I.I. Ozigis and I.A. Adetunde, 2009. Pneumatic and hydraulic systems in coal fluidized bed combustor. Am. J. Eng. Applied Sci., 2: 88-95. DOI: 10.3844/ajeassp.2009.88.95

Orlando, N. and E. Benvenuti, 2016. Advanced XFEM simulation of pull-out and debonding of steel bars and FRP-reinforcements in concrete beams. Am. J. Eng. Applied Sci., 9: 746-754.

DOI: 10.3844/ajeassp.2016.746.754

Pannirselvam, N., P.N. Raghunath and K. Suguna, 2008. Neural network for performance of glass fibre reinforced polymer plated RC beams. Am. J. Eng. Applied Sci., 1: 82-88.

DOI: 10.3844 ajeassp.2008.82.88

Pattanasethanon, S., 2010. The solar tracking system by using digital solar position sensor. Am. J. Eng. Applied Sci., 3: 678-682. DOI: 10.3844/ajeassp.2010.678.682

Pérez-de León, G., V.E. Lamberti, R.D. Seals, T.M. Abu-Lebdeh and S.A. Hamoush 2016. Gas atomization of molten metal: Part I. Numerical modeling conception. Am. J. Eng. Applied Sci., 9: 303-322. DOI: 10.3844/ajeassp.2016.303.322

Petrescu, F. and R. Petrescu, 1995a. Contributions to the optimization of the polynomial motion laws of the stick from the internal combustion engine distribution mechanism. Bucharest.

Petrescu, F. and R. Petrescu, 1995b. Contributions to the synthesis of distribution mechanisms of internal combustion engines. Bucharest.

Petrescu, F. and R. Petrescu, 1997a. Dynamics of cam mechanisms (exemplified on the classic distribution mechanism). Bucharest. 
Petrescu, F. and R. Petrescu, 1997b. Contributions to the synthesis of the distribution mechanisms of internal combustion engines with Cartesian coordinate method. Bucharest.

Petrescu, F. and R. Petrescu, 1997c. Contributions to the maximization of polynomial laws for the active stroke of the distribution mechanism from internal combustion engines. Bucharest.

Petrescu, F. and R. Petrescu, 2000a. Synthesis of distribution mechanisms by the rectangular coordinate method (Cartesian). Craiova University, Craiova.

Petrescu, F. and R. Petrescu, 2000b. The design (synthesis) of cam mechanism by the polar coordinates method (triangle method). Craiova University, Craiova.

Petrescu, F. and R. Petrescu, 2002a. Motion laws for cam mechanisms. Proceedings of the 7th National Symposium with International Participation Computer Assisted Design, (CAD’ 02), Braşov, pp: 321-326.

Petrescu, F. and R. Petrescu, 2002b. Dynamics of cam mechanisms. Proceedings of the National Symposium with International Participation Computer Assisted Design, (CAD’ 02), Brasov, pp: 327-332.

Petrescu, F. and R. Petrescu, 2003. Some elements regarding the improvement of the engine design. Proceedings of the 8th National Symposium, Descriptive Geometry, Technical Graphics and Design, (GTD' 03), Braşov, pp: 353-358.

Petrescu, F. and R. Petrescu, 2005a. The cam design for a better efficiency. Proceedings of the International Conference on Engineering Graphics and Design, (EGD' 05), Bucharest, pp: 245-248.

Petrescu, F. and R. Petrescu, 2005b. Contributions at the dynamics of cams. Proceedings of the 9th IFToMM International Symposium on Theory of Machines and Mechanisms, (TMM' 05), Bucharest, Romania, pp: 123-128.

Petrescu, F. and R. Petrescu, 2005c. Determining the dynamic efficiency of cams. Proceedings of the 9th IFToMM International Symposium on Theory of Machines and Mechanisms, (TMM' 05), Bucharest, Romania, pp: 129-134.

Petrescu, F. and R. Petrescu, 2005d. An original internal combustion engine. Proceedings of the 9th IFToMM International Symposium on Theory of Machines and Mechanisms, (TMM' 05), Bucharest, Romania, pp: $135-140$.

Petrescu, F. and R. Petrescu, 2005e. Determining the mechanical efficiency of Otto engine's mechanism. Proceedings of the 9th IFToMM International Symposium on Theory of Machines and Mechanisms, (TMM' 05), Bucharest, Romania, pp: 141-146.

Petrescu, R.V. and F.I. Petrescu, 2013a. Lockheed Martin. 1st Edn., BoD-Books on Demand, ISBN-10: 3848230739, pp: 114.

Petrescu, R.V. and F.I. Petrescu, 2013b. Northrop. 1st Edn., CreateSpace, pp: 96.
Petrescu, R.V. and F.I. Petrescu, 2013c. The Aviation History or New Aircraft I Color. 1st Edn., CreateSpace, pp: 292.

Petrescu, F.I.T. and R.V. Petrescu, 2013d. Forces and efficiency of cams. Int. Rev. Mech. Eng. J., 7: 507-511.

Petrescu, F.I.T. and R.V. Petrescu, 2013e. Cams with high efficiency. Int. Rev. Mech. Eng. J., 7: 599-606.

Petrescu, F.I.T. and R.V. Petrescu, 2013f. An algorithm for setting the dynamic parameters of the classic distribution mechanism. Int. Rev. Modell. Simulat. J., 6: 1637-1641.

Petrescu, F.I.T. and R.V. Petrescu, 2013g. Dynamic synthesis of the rotary cam and translated tappet with roll. Int. Rev. Modell. Simulat. J., 6: 600-607.

Petrescu, F.I. and R.V. Petrescu, 2012. New Aircraft II. 1st Edn., Books On Demand, pp: 138.

Petrescu, F.I. and R.V. Petrescu, 2011. Memories about Flight. 1st Edn., CreateSpace, pp: 652.

Petrescu, F.I.T. and R.V. Petrescu, 2014a. Parallel moving mechanical systems. Independent J. Manage. Product., 5: 564-580.

Petrescu, F.I.T. and R.V. Petrescu, 2014b. Cam gears dynamics in the classic distribution. Independent J. Manage. Product., 5: 166-185.

Petrescu, F.I.T. and R.V. Petrescu, 2014c. Highefficiency gears synthesis by avoid the interferences. Independent J. Manage. Product., 5: 275-298.

Petrescu, F.I.T. and R.V. Petrescu, 2014d. Gear design. J. ENGEVISTA, 16: 313-328.

Petrescu, F.I.T. and R.V. Petrescu, 2014e. Kinetostatic of the 3R dyad (or 2R Module). J. ENGEVISTA, 16: 314-321.

Petrescu, F.I.T. and R.V. Petrescu, 2014f. Balancing Otto engines. Int. Rev. Mech. Eng. J., 8: 473-480.

Petrescu, F.I.T. and R.V. Petrescu, 2014g. Machine equations to the classical distribution. Int. Rev. Mech. Eng. J., 8: 309-316.

Petrescu, F.I.T. and R.V. Petrescu, 2014h. Forces of internal combustion heat engines. Int. Rev. Modell. Simulat. J., 7: 206-212.

Petrescu, F.I.T. and R.V. Petrescu, 2014i. Determination of the yield of internal combustion thermal engines. Int. Rev. Mech. Eng. J., 8: 62-67.

Petrescu, F.I.T. and R.V. Petrescu, 2015a. Forces at the main mechanism of a railbound forging manipulator. Independent J. Manage. Product., 6: 904-921.

Petrescu, F.I.T. and R.V. Petrescu, 2015b. Kinematics at the main mechanism of a railbound forging manipulator. Independent J. Manage. Product., 6: 711-729.

Petrescu, F.I.T. and R.V. Petrescu, 2015c. Machine motion equations. Independent J. Manage. Product., 6: 773-802.

Petrescu, F.I.T. and R.V. Petrescu, 2015d. Presenting a railbound forging manipulator. Applied Mechan. Mater., 762: 219-224.

Petrescu, F.I.T. and R.V. Petrescu, 2015e. About the anthropomorphic robots. J. ENGEVISTA, 17: 1-15 
Petrescu, F.I.T. and R.V. Petrescu, 2016. An Otto engine dynamic model. Independent J. Manage. Product., 7: 038-048

Petrescu, F.I.T., 2018. About the nuclear particles' structure and dimensions. Comp. Part. Mech. DOI: $10.1007 / \mathrm{s} 40571-018-0206-7$

Petrescu, F.I.T., 2015a. Geometrical synthesis of the distribution mechanisms. Am. J. Eng. Applied Sci., 8: 63-81. DOI: 10.3844/ajeassp.2015.63.81

Petrescu, F.I.T., 2015b. Machine motion equations at the internal combustion heat engines. Am. J. Eng. Applied Sci., 8: 127-137.

DOI: 10.3844/ajeassp.2015.127.137

Petrescu, F.I.T., 2012a. Cold nuclear fusion. Plasma Phys. Fusion Technol., 44: 100-100.

Petrescu, F.I.T., A. Apicella, R.V. Petrescu, S.P. Kozaitis and R.B. Bucinell et al., 2016. Environmental protection through nuclear energy. Am. J. Applied Sci., 13: 941-946.

Petrescu, R.V., R. Aversa, B. Akash, F. Berto and A. Apicella et al., 2017a. Forces of a 3R robot. J. Mechatron. Robot., 1: 1-14. DOI: $10.3844 /$ jmrsp.2017.1.14

Petrescu, R.V., R. Aversa, B. Akash, F. Berto and A. Apicella et al., 2017b. Direct geometry and cinematic to the MP-3R systems. J. Mechatron. Robot., 1: 15-23. DOI: 10.3844/jmrsp.2017.15.23

Petrescu, R.V., R. Aversa, B. Akash, F. Berto and A. Apicella et al., 2017c. Dynamic elements at MP3R. J. Mechatron. Robot., 1: 24-37. DOI: $10.3844 / \mathrm{jmrsp} .2017 .24 .37$

Petrescu, R.V., R. Aversa, B. Akash and A. Apicella et al., 2017d. Geometry and direct kinematics to MP3R with $4 \times 4$ operators. J. Mechatron. Robot., 1: 38-46. DOI: $10.3844 / \mathrm{jmrsp} .2017 .38 .46$

Petrescu, R.V., R. Aversa, A. Apicella and F.I.T. Petrescu, 2018a. Total Static Balancing and Kinetostatics of the 3R Base Cinematic Chain. J. Mechatron. Robot., 2: 1-13. DOI: 10.3844/jmrsp.2018.1.13

Petrescu, R.V., R. Aversa, A. Apicella and F.I.T. Petrescu, 2018b. Switching from Flat to Spatial Motion to 3R Mechatronic Systems. J. Mechatron. Robot., 2: 14-22. DOI: 10.3844/jmrsp.2018.14.22

Petrescu, R.V., R. Aversa, A. Apicella and F.I.T. Petrescu, 2018c. The dynamics of the planar cinematic balanced chain at the plan module $3 \mathrm{R}$. J. Mechatron. Robot., 2: 23-34.

DOI: $10.3844 /$ jmrsp.2018.23.34

Petrescu, R.V., R. Aversa, A. Apicella and F.I.T. Petrescu, 2018d. Dynamic Kinematics of the Plan Balanced Chain at the Planar Module 3R. J. Mechatron. Robot., 2: 35-44. DOI: 10.3844/jmrsp.2018.35.44

Petrescu, F.I.T. and J.K. Calautit, 2016a. About nano fusion and dynamic fusion. Am. J. Applied Sci., 13: 261-266.
Petrescu, F.I.T. and J.K. Calautit, 2016b. About the light dimensions. Am. J. Applied Sci., 13: 321-325.

Petrescu FIT., 2012b. China. 1st Edn., CreateSpace Independent Publisher, ISBN-13: 978-1469973623, pp: 232.

Pisello, A.L., G. Pignatta, C. Piselli, V.L. Castaldo and F. Cotana, 2016. Investigating the dynamic thermal behavior of building envelope in summer conditions by means of in-field continuous monitoring. Am. J. Eng. Applied Sci., 9: 505-519.

DOI: 10.3844/ajeassp.2016.505.519

Pourmahmoud, N., 2008. Rarefied gas flow modeling inside rotating circular cylinder. Am. J. Eng. Applied Sci., 1: 62-65.

DOI: 10.3844/ajeassp.2008.62.65

Pravettoni, M., C.S.P. Lòpez and R.P. Kenny, 2016. Impact of the edges of a backside diffusive reflector on the external quantum efficiency of luminescent solar concentrators: experimental and computational approach. Am. J. Eng. Applied Sci., 9: 53-63. DOI: 10.3844/ajeassp.2016.53.63

Qutbodin, K., 2010. Merging autopilot/flight control and navigation-flight management systems. Am. J. Eng. Applied Sci., 3: 629-630. DOI: 10.3844 /ajeassp.2010.629.630

Rajbhandari, S., Z. Ghassemlooy and M. Angelova, 2011. The performance of a dual header pulse interval modulation in the presence of artificial light interferences in an indoor optical wireless communications channel with wavelet denoising. Am. J. Eng. Applied Sci., 4: 513-519. DOI: 10.3844 /ajeassp.2011.513.519

Rajput, R.S., S. Pandey and S. Bhadauria, 2016. Correlation of biodiversity of algal genera with special reference to the waste water effluents from industries. Am. J. Eng. Applied Sci., 9: 1127-1133. DOI: 10.3844/ajeassp.2016.1127.1133

Raptis, K.G., G.A. Papadopoulos, T.N. Costopoulos and A.D. Tsolakis, 2011. Experimental study of load sharing in roller-bearing contact by caustics and photoelasticity. Am. J. Eng. Applied Sci., 4: 294-300. DOI: 10.3844/ajeassp.2011.294.300

Rama, G., D. Marinkovic and M. Zehn, 2016. Efficient co-rotational 3-node shell element. Am. J. Eng. Applied Sci., 9: 420-431. DOI: 10.3844 /ajeassp.2016.420.431

Rea, P. and E. Ottaviano, 2016. Analysis and mechanical design solutions for sit-to-stand assisting devices. Am. J. Eng. Applied Sci., 9: 1134-1143. DOI: 10.3844/ajeassp.2016.1134.1143

Riccio, A., U. Caruso, A. Raimondo and A. Sellitto, 2016a. Robustness of XFEM method for the simulation of cracks propagation in fracture mechanics problems. Am. J. Eng. Applied Sci., 9: 599-610. DOI: 10.3844/ajeassp.2016.599.610 
Riccio, A., R. Cristiano and S. Saputo, 2016b. A brief introduction to the bird strike numerical simulation. Am. J. Eng. Applied Sci., 9: 946-950.

DOI: 10.3844/ajeassp.2016.946.950

Rich, F. and M.A. Badar, 2016. Statistical analysis of auto dilution Vs manual dilution process in inductively coupled plasma spectrometer tests. Am. J. Eng. Applied Sci., 9: 611-624. DOI: 10.3844 /ajeassp.2016.611.624

Rohit, K. and S. Dixit, 2016. Mechanical properties of waste Biaxially Oriented Polypropylene Metallized Films (BOPP), LLDPE: LDPE Films with Sisal Fibres. Am. J. Eng. Applied Sci., 9: 913-920. DOI: 10.3844/ajeassp.2016.913.920

Rulkov, N.F., A.M. Hunt, P.N. Rulkov and A.G. Maksimov, 2016. Quantization of map-based neuronal model for embedded simulations of neurobiological networks in real-time. Am. J. Eng. Applied Sci., 9: 973-984. DOI: 10.3844/ajeassp.2016.973.984

Saikia, A. and N. Karak, 2016. Castor oil based epoxy/clay nanocomposite for advanced applications. Am. J. Eng. Applied Sci., 9: 31-40. DOI: 10.3844 /ajeassp.2016.31.40

Sallami, A., N. Zanzouri and M. Ksouri, 2016. Robust diagnosis of a DC motor by bond graph approach. Am. J. Eng. Applied Sci., 9: 432-438. DOI: 10.3844/ajeassp.2016.432.438

Samantaray, K.S., S. Sahoo and C.S. Rout, 2016. Hydrothermal synthesis of $\mathrm{CuWO}_{4}$-reduced graphene oxide hybrids and supercapacitor application. Am. J. Eng. Applied Sci., 9: 584-590. DOI: 10.3844 /ajeassp.2016.584.590

Semin, A.R. Ismail and R.A. Bakar, 2009a. Combustion temperature effect of diesel engine convert to compressed natural gas engine. Am. J. Eng. Applied Sci., 2: 212-216.

DOI: 10.3844 /ajeassp.2009.212.216

Semin, A.R. Ismail and R.A. Bakar, 2009b. Effect of diesel engine converted to sequential port injection compressed natural gas engine on the cylinder pressure Vs crank angle in variation engine speeds. Am. J. Eng. Applied Sci., 2: 154-159. DOI: 10.3844/ajeassp.2009.154.159

Semin S., A.R. Ismail and R.A. Bakar, 2009c. Diesel engine convert to port injection $\mathrm{CNG}$ engine using gaseous injector nozzle multi holes geometries improvement: A review. Am. J. Eng. Applied Sci., 2: 268-278. DOI: 10.3844/ajeassp.2009.268.278

Semin and R.A. Bakar, 2008. A technical review of compressed natural gas as an alternative fuel for internal combustion engines. Am. J. Eng. Applied Sci., 1: 302-311.

DOI: 10.3844/ajeassp.2008.302.311

Sepúlveda, J.A.M., 2016. Outlook of municipal solid waste in Bogota (Colombia). Am. J. Eng. Applied Sci., 9: 477-483.

DOI: $10.3844 /$ ajeassp.2016.477.483
Serebrennikov, A., D. Serebrennikov and Z. Hakimov, 2016. Polyethylene pipeline bending stresses at an installation. Am. J. Eng. Applied Sci., 9: 350-355. DOI: 10.3844 /ajeassp.2016.350.355

Shanmugam, K., 2016. Flow dynamic behavior of fish oil/silver nitrate solution in mini-channel, effect of alkane addition on flow pattern and interfacial tension. Am. J. Eng. Applied Sci., 9: 236-250.

DOI: 10.3844/ajeassp.2016.236.250

Shruti, 2016. Comparison in cover media under stegnography: Digital media by hide and seek approach. Am. J. Eng. Applied Sci., 9: 297-302. DOI: 10.3844/ajeassp.2016.297.302

Suarez, L., T.M. Abu-Lebdeh, M. Picornell and S.A. Hamoush, 2016. Investigating the role of fly ash and silica fume in the cement hydration process. Am. J. Eng. Applied Sci., 9: 134-145.

DOI: 10.3844 /ajeassp.2016.134.145

Syahrullah, O.I. and N. Sinaga, 2016. Optimization and prediction of motorcycle injection system performance with feed-forward back-propagation method Artificial Neural Network (ANN). Am. J. Eng. Applied Sci., 9: 222-235. DOI: 10.3844/ajeassp.2016.222.235

Taher, S.A., R. Hematti and M. Nemati, 2008. Comparison of different control strategies in GAbased optimized UPFC controller in electric power systems. Am. J. Eng. Applied Sci., 1: 45-52.

DOI: 10.3844/ajeassp.2008.45.52

Theansuwan, W. and K. Triratanasirichai, 2011. The biodiesel production from roast thai sausage oil by transesterification reaction. Am. J. Eng. Applied Sci., 4: 130-132.

DOI: 10.3844 ajeassp.2011.130.132

Thongwan, T., A. Kangrang and S. Homwuttiwong, 2011. An estimation of rainfall using fuzzy setgenetic algorithms model. Am. J. Eng. Applied Sci., 4: 77-81. DOI: 10.3844/ajeassp.2011.77.81

Tourab, W., A. Babouri and M. Nemamcha, 2011. Experimental study of electromagnetic environment in the vicinity of high voltage lines. Am. J. Eng. Applied Sci., 4: 209-213.

DOI: 10.3844/ajeassp.2011.209.213

Tsolakis, A.D. and K.G. Raptis, 2011. Comparison of maximum gear-tooth operating bending stresses derived from niemann's analytical procedure and the finite element method. Am. J. Eng. Applied Sci., 4: 350-354. DOI: 10.3844/ajeassp.2011.350.354

Wang, L., T. Liu, Y. Zhang and X. Yuan, 2016. A methodology for continuous evaluation of cloud resiliency. Am. J. Eng. Applied Sci., 9: 264-273. DOI: 10.3844 /ajeassp.2016.264.273 
Wang, J. and Y. Yagi, 2016. Fragment-based visual tracking with multiple representations. Am. J. Eng. Applied Sci., 9: 187-194.

DOI: 10.3844/ajeassp.2016.187.194

Waters, C., S. Ajinola and M. Salih, 2016. Dissolution sintering technique to create porous copper with sodium chloride using polyvinyl alcohol solution through powder metallurgy. Am. J. Eng. Applied Sci., 9: 155-165.

DOI: 10.3844 /ajeassp.2016.155.165

Wessels, L. and H. Raad, 2016. Recent advances in point of care diagnostic tools: A review. Am. J. Eng. Applied Sci., 9: 1088-1095. DOI: 10.3844/ajeassp.2016.1088.1095

Yeargin, R., R. Ramey and C. Waters, 2016. Porosity analysis in porous brass using dual approaches. Am. J. Eng. Applied Sci., 9: 91-97. DOI: 10.3844/ajeassp.2016.91.97

You, M., X. Huang, M. Lin, Q. Tong and X. Li et al., 2016. Preparation of $\mathrm{LiCoMnO}_{4}$ assisted by hydrothermal approach and its electrochemical performance. Am. J. Eng. Applied Sci., 9: 396-405. DOI: 10.3844/ajeassp.2016.396.405

Zeferino, R.S., J.A.R. Ramón, E. de Anda Reyes, R.S. González and U. Pal, 2016. Large scale synthesis of $\mathrm{ZnO}$ nanostructures of different morphologies through solvent-free mechanochemical synthesis and their application in photocatalytic dye degradation. Am. J. Eng. Applied Sci., 9: 41-52. DOI: 10.3844/ajeassp.2016.41.52

Zhao, B., 2013. Identification of multi-cracks in the gate rotor shaft based on the wavelet finite element method. Am. J. Eng. Applied Sci., 6: 309-319. DOI: 10.3844/ajeassp.2013.309.319

Zheng, H. and S. Li, 2016. Fast and robust maximum power point tracking for solar photovoltaic systems. Am. J. Eng. Applied Sci., 9: 755-769. DOI: 10.3844 /ajeassp.2016.755.769
Zotos, I.S. and T.N. Costopoulos, 2009. On the use of rolling element bearings' models in precision maintenance. Am. J. Eng. Applied Sci., 2: 344-352. DOI: 10.3844 /ajeassp.2009.344.352

Zulkifli, R., K. Sopian, S. Abdullah and M.S. Takriff, 2008. Effect of pulsating circular hot air jet frequencies on local and average nusselt number. Am. J. Eng. Applied Sci., 1: 57-61. DOI: 10.3844/ajeassp.2008.57.61

Zulkifli, R., K. Sopian, S. Abdullah and M.S. Takriff, 2009. Experimental study of flow structures of circular pulsating air jet. Am. J. Eng. Applied Sci., 2: 171-175. DOI: 10.3844/ajeassp.2009.171.175

Zurfi, A. and J. Zhang, 2016a. Model identification and wall-plug efficiency measurement of white LED modules. Am. J. Eng. Applied Sci., 9: 412-419. DOI: 10.3844/ajeassp.2016.412.419

Zurfi, A. and J. Zhang, 2016b. Exploitation of battery energy storage in load frequency control -A literature survey. Am. J. Eng. Applied Sci., 9: 11731188. DOI: 10.3844 /ajeassp.2016.1173.1188

\section{Figure Sources}

Fig. 1: https://static2.playtech.ro/wpcontent/uploads/2019/02/boeing-avion-autonom-1170x658.jpg Fig. 2: https://static2.playtech.ro/wpcontent/uploads/2019/02/boeing-avion-autonom.png Fig. 3:

https://upload.wikimedia.org/wikipedia/commons/thumb/4/4a/ B-1B_over_the pacific_ocean.jpg/1024px-B1B_over_the_pacific_ocean.jpg

Fig. 4:

https://upload.wikimedia.org/wikipedia/commons/thumb/a/ab/ B-2_Spirit_4.jpg/1024px-B-2_Spirit_4.jpg

Fig. 5:

https://upload.wikimedia.org/wikipedia/commons/thumb/6/6e/ B-52_over_Afghanistan.JPG/1280px-B52_over_Afghanistan.JPG 